\title{
200 ANOS NÃO SÃO 200 DIAS: HISTÓRIA, PROTAGONISMO E ESTRATÉGIA DE MULHERES NEGRAS NA IRMANDADE DA BOA MORTE (1820 - 2020)
}

\author{
Mariana Fernandes Rodrigues Barreto Regis ${ }^{1}$ \\ DOI 10.26512/revistacalundu.v4i2.34574
}

\begin{abstract}
Resumo
A Irmandade da Nossa Senhora da Boa Morte de Cachoeira - BA, completou 200 anos no ano de 2020 e sua trajetória é essencial para a preservação das tradições provenientes da diáspora africana. A Irmandade é um símbolo de resistência e exemplo de estratégias para a criação e a manutenção de práticas sociais e culturais que combateram a ordem colonial na Bahia e no Brasil. Além sua importância para as religiões de matriz africana e para a luta antiescravista, a influência da Irmandade se disseminou em diversos símbolos sociais e culturais da população negra, porém muitos nuances dessa história ainda são desconhecidos ou ignorados pela historiografia tradicional devido a um problema de "falta de fontes". Esses e outros "problemas" de estudos das tradições afrobrasileiras devem ser questionados para que possamos compreender até que ponto interferem em trabalhos sobre tais organizações e qual a importância da oralidade na transmissão, perpetuação e estudos destas tradições.
\end{abstract}

Palavras-chave: Irmandade da Boa Morte. Mulheres da Boa Morte. História Oral. Oralidade. Religiões de Matriz Africana. Candomblé.

\section{AÑOS NO SON 200 DÍAS: HISTORIA, PROTAGONISMO Y ESTRATEGIA DE LAS MUJERES NEGRAS EM LA IRMANDADE DA BOA MORTE (1820 - 2020)}

\begin{abstract}
Resumen
La Irmandade da Nossa Senhora da Boa Morte de Cachoeira (Bahia) cumplió 200 años en 2020 y su trayectoria es fundamental para la preservación de las tradiciones de la diáspora africana. La Irmandade es símbolo de resistencia y ejemplo de estrategias para la creación y mantenimiento de prácticas sociales y culturales que combatieron el orden colonial en Bahía y Brasil. Además de su importancia para las religiones de base africana y para la lucha contra la esclavitud, la influencia de la Irmandade se ha extendido a varios símbolos sociales y culturales de la población negra, sin embargo muchos matices de esta historia aún son desconocidos o ignorados por la historiografía tradicional debido a un problema de "ausencia de fuentes". Estos y otros "problemas" de los estudios de las tradiciones afrobrasileñas deben ser cuestionados para que podamos entender hasta qué
\end{abstract}

\footnotetext{
${ }^{1}$ Possui mestrado em História pela Universidade de Brasília (2016), na linha de pesquisa: História Social e suas múltiplas formas. Trabalha com Irmandades Negras na América Portuguesa e Metodologia da História. Graduação em História pela Universidade de Brasília (2013). Pesquisadora Associada do Observatório da Saúde da População Negra NESP/CEAM/UnB. Email: marianaregis@ gmail.com
} 
punto interfieren en el trabajo de tales organizaciones y la importancia de la oralidad en la transmisión, perpetuación y estudios de estas tradiciones.

Palabras clave: Irmandade da Nossa Senhora da Boa Morte. Mujeres de la Boa Morte. Historia oral. Oralidad. Religiones matriciales africanas. Candomblé.

\title{
200 anos não são 200 dias
}

\begin{abstract}
"Nossos antepassados, as nossas irmãs eram intituladas "as mulheres do partido alto", então elas trabalhavam em prol dos próprios irmãos... de liberdade, trabalharam para conseguir as cartas de alforria ou as vezes até fuga para os irmãos que eram necessitados e precisavam de ajuda. Então, elas fizeram um movimento feminino pra poder ajudar as irmãs... as outras irmãs a ter sua liberdade, porque nem só a carta de alforria dava liberdade como até hoje: Eles dizem que nós somos libertos mas a gente continua embaixo do poder aquisitivo, sempre temos que pagar tudo, tem que pedir licença pra tudo, então a escravidão continua "por debaixo dos panos", mas a gente continua ainda naquele regime escravocrata ali. Então elas faziam esse movimento pra fazer essa ajuda pros nossos irmãos serem libertados, terem mais seus direitos, porque a liberdade mesmo dos irmãos escravos é estar com deus quando morrer. A liberdade da alma, do corpo é estar com mamãe lá em cima quando a gente partir desse pra outro mundo." - Dona Nilza Prado de Carvalho - Irmã da Boa Morte. (TVE Bahia, 2019)
\end{abstract}

No meio do Recôncavo baiano, entre muito samba de roda, maniçoba e a bela vista do rio Paraguaçu, se encontra a Irmandade da Nossa Senhora da Boa Morte, localizada na rua Treze de maio, coração de Cachoeira. Inevitavelmente essas duas histórias, a da cidade de Cachoeira e a da Boa Morte estão entrelaçadas e contam muito sobre a trajetória de mulheres pretas no Brasil.

O legado da Irmandade da Nossa Senhora da Boa Morte de Cachoeira é incontestável, mesmo que seu valor e sua história sejam, em alguns momentos, negligenciadas pela historiografia tradicional e não sejam o foco de interesse de pesquisadores de várias áreas do conhecimento. Através de seus 200 anos, recém completados e comemorados no ano de 2020, a Irmandade da Boa Morte atravessou vários dos períodos históricos brasileiros, trazendo para os afrodescendentes da diáspora, um marco referencial e representando uma instituição social, religiosa e política poderosa, capaz de sobreviver ao sistema colonial escravista e seu período subsequente. Além de lutarem contra a escravidão, comprarem alforrias e possibilitarem um novo horizonte para 
cativos, não podemos esquecer de um ponto crucial na constituição da Irmandade: ela era e ainda é constituída exclusivamente por mulheres negras.

Paralelamente, na contramão das instituições tradicionais portuguesas, a Irmandade da Boa Morte transmitiu seus ensinamentos e perpetuou suas tradições e sua organização de maneira exclusivamente oral, possibilitando desta maneira, a perpetuação das tradições espirituais experienciadas em África, possibilitando a criação do Candomblé e de outras religiões de matriz africana. A Boa Morte, além de tudo, representa mais profundamente: estratégia e existência de mulheres negras.

\section{O que são as irmandades negras?}

A história do Brasil é atravessada pela história da escravização de africanos. Levando em consideração que a maior parcela da população brasileira é afrodescendente declarada, (IBGE, 2010) assim sendo, a contribuição da população negra para a constituição do que conhecemos hoje como Brasil foi e é essencial desde o período colonial. O legado afro-brasileiro se faz presente em todos os âmbitos da vida social brasileira, nas manifestações culturais, intelectuais, musicais, religiosas, culinárias, econômicas, sociais entre outras. Neste sentido, alguns temas ou objetos, manifestações e formas de expressões negras são essenciais para a compreensão e valorização da cultura e da população negra brasileira. As histórias das organizações negras ao longo da formação do Brasil são extremamente importantes para a continuidade da construção de narrativas antirracistas, contribuindo para a compreensão da importância desses objetos na nossa formação cultural e da nossa sociedade. Mesmo que pessoas negras sejam as maiores vítimas dos problemas advindos da questão racial nos dias de hoje, compreender a colaboração e o legado do povo preto no Brasil é uma necessidade importante para toda a sociedade.

As Irmandades Negras representaram no Brasil escravista, uma das instituições responsáveis pela transformação e sobrevivência das tradições religiosas e espirituais africanas ao passo que foram essenciais para a criação destas novas práticas afrobrasileiras. Assim sendo, a Irmandade da Nossa Senhora da Boa Morte, fundada aproximadamente no ano de 1810 em Salvador - Bahia e transferida para a cidade de Cachoeira - Bahia, no ano de 1820 e em funcionamento até os dias atuais, representa de maneira emblemática esse passado de transformação vivida pelos africanos e africanas da 
diáspora, além de recriar em terras brasileiras, suas práticas culturais tão importantes para a sobrevivência dos povos africanos na diáspora e seus descendentes.

No campo religioso, o sistema colonial fez com que as concepções de mundo africanas trazidas pela diáspora (HALL, 2006, p.28) fossem recriminadas, pois além da catequização de índios e de africanos escravizados como estratégia de um projeto de dominação e exploração, também era conveniente para tal projeto, combater os rituais e práticas espirituais que não fossem cristãs nos moldes eurocêntricos.

Dentro deste contexto, as religiosidades africanas se perpetuaram no Brasil por meio da resistência, transformação e adaptação do que existia em diversas etnias em África e se reorganizaram na América Portuguesa sofrendo influência da cultura europeia e indígena. Faz-se necessário ressaltar que os termos étnicos que diferenciavam estes africanos se criaram com a diáspora compulsória e com o trabalho escravo, pois quando se volta o olhar para a população cativa é possível perceber que ali se encontravam pessoas de diversas etnias colocadas em categorias identitárias impostas pelo poder colonial. (REIS, 1996, p.5)

As práticas espirituais vieram como herança dos africanos escravizados e aqui se transformaram em religiões brasileiras de matrizes africanas, onde os rituais foram trazidos através da memória e foram transmitidos majoritariamente de maneira oral para seus descendentes. Ao longo das décadas e séculos, com as transformações do Brasil, estas representações foram sendo transformadas ao mesmo tempo em que sofriam intervenções culturais do ambiente no qual se construíram.

No contexto colonial, estes africanos foram arrancados de suas raízes e submetidos a situações perversas, embarcados na travessia para as terras da América para a submissão ao trabalho compulsório e para que este empreendimento colonial fosse possível, era necessário tentar controlar várias experiências de vida dos africanos. REIS (1996, p.4), atenta para o importante fato de que senhores e escravos conviviam em um espaço de negociação e para que fosse possível a perpetuação do sistema escravocrata, era necessário que os senhores "negociassem" com seus escravos, segundo suas palavras, entre os extremos da "coerção e persuasão". Ao mesmo tempo que o sistema vigente tentava minguar as possibilidades de revoltas ou rebeliões, escravizados e seus descentes se utilizavam de dispositivos internos, como as Irmandades Negras para criar um espaço de sobrevivência e criação de identidades. Neste sentido, esse espaço de negociação viabilizou o nascimento destas novas práticas sociais, culturais e políticas dos negros da diáspora. 
No sistema colonial, as raízes culturais deveriam ser "esquecidas" pelos africanos, ou pelo menos deixadas de lado. No campo religioso, um dos meios encontrados para se realizar a dominação destes povos africanos, era tentar fazer com que estes vivessem o mais harmonicamente possível, para isso os colonizadores forçavam os escravizados a substituírem seus cultos ancestrais tradicionais pela religião cristã do homem branco, e assim, foi feita a tentativa de esquecimento da cultura religiosa de origem. Tal empreendimento resultou em manifestações que conseguiram se reinventar e mesclar o culto ancestral com as religiosidades do "novo mundo".

Em “A África e os Africanos no Novo mundo”, John Thornton (2004, p. 253,254) explica que múltiplas culturas independentes foram trazidas para a América na diáspora, pois os africanos não compartilhavam de valores culturais homogêneos, sendo assim, o mecanismo do comércio de escravos separava estes indivíduos de seus pares, diferentemente dos processos migratórios dos europeus, onde no novo lar, os indivíduos se colocavam em comunidades que partilham de valores em comum. No caso dos africanos, milhares de indivíduos de diferentes culturas e etnias começaram uma interação forçada, iniciando assim, a criação de uma nova cultura nas Américas desde a travessia dentro dos navios negreiros. Para a criação desta nova cultura, a referência utilizada foi o que as diversas culturas africanas possuíam de semelhante ou comum, usando como ponto de ligação a cultura europeia. Ao dizer que estes escravizados priorizaram um denominador comum na hora de construir uma nova cultura, é preciso atentar para o fato de que segundo Thornton, estas diferentes culturas tinham sim práticas em comum que existiam entre espaços muito distantes devido a trocas culturais, sociais e mercantis. (THORNTON, 2004, p.347)

Ao serem lançados nos navios negreiros para a América, africanos de diversas regiões do continente e de diversos povos foram obrigados a encontrar suas semelhanças nos seus modos de viver para que pudessem conviver entre si. Nesse sentido, o culto aos santos católicos, em alguma medida, auxiliou os africanos provenientes de diferentes origens e tradições, a unir seus próprios referenciais com as diferentes "revelações" trazidas por meio dos santos católicos. (THORNTON, 2004, p.347-351)

Com a necessidade de construção e sobrevivência dos escravizados nas terras da América, entre várias instituições que serviram como mecanismos importantes para viabilizar uma organização social, as irmandades católicas representaram um espaço importante para a criação de novos modos de viver.

As irmandades católicas possibilitaram a construção de espaços de devoção e fé, 
organização política e social por toda a América Lusa. No caso das irmandades compostas por africanos e seus descendentes, chamadas de "Irmandades Negras", além destas funções, elas representam um dos espaços onde se possibilitou a reconstrução cultural destes povos nas terras americanas. Dentro de uma irmandade, o irmão associado a ela, além de participar de atividades religiosas ligadas ao culto do santo ou da santa de devoção, também podia desfrutar dos privilégios e auxílios promovidos por esta instituição. Entre as funções de um irmão ou irmã devoto filiado a uma irmandade, estão as contribuições financeiras, obrigações nas funções da igreja e as regras de conduta colocadas pela igreja da qual é filiado. (REGIS, 2016, p.100-101)

\begin{abstract}
A irmandade representava um espaço de relativa autonomia negra, no qual seus membros - em torno das festas, assembleias, eleições, funerais, missas e da assistência mútua - construíam identidades sociais significativas, no interior de um mundo às vezes sufocante e sempre incerto. A irmandade era uma espécie de família ritual, em que africanos desenraizados de suas terras viviam e morriam solidariamente. Idealizadas pelos brancos como um mecanismo de domesticação do espírito africano, através da africanização da religião dos senhores, elas vieram a constituir um instrumento de identidade e solidariedade coletivas. (REIS, 1996, p.4)
\end{abstract}

Os integrantes de uma irmandade participavam de atividades relacionadas à devoção e gozavam de privilégios e auxílios. Como obrigação, era necessária a colaboração em vários sentidos, inclusive financeiramente, assumindo obrigações com a igreja e suas atividades. Esse ambiente de autonomia dentro da imposição escravista funcionava como um respiro onde era possível o nascimento de um novo espaço, de criação e reconstrução de seus elos ancestrais e de construção de identidade, enquanto que para os brancos e senhores de escravos, as irmandades negras eram um ambiente de dominação e domesticação, visto que a associação a uma irmandade representava o sucesso na tentativa de conversão a fé católica. Paralelamente, os escravizados encaravam este mesmo ambiente como um local de construção de identidade e solidariedade coletivas.

A riqueza maior do estudo das irmandades talvez seja no profundo significado histórico que elas apresentam. Foram e são instituições que se espelham e retratam os diversos momentos e contextos históricos nos quais se inserem. Com elas, o catolicismo e a Igreja Católica amoldam-se à realidade na qual se propagam. Nada de anacronismos históricos. As irmandades caracterizam sempre o seu momento e o seu ambiente, dando origem à diversidade de formas, 
por um lado, e à fluidez e imprecisão de suas denominações por outro (BOSCHI, 1986, p.12).

As irmandades católicas negras foram substanciais para a formação cultural, política e social do Brasil, representando um espaço de autonomia dentro da lógica do sistema colonial, porém, é importante lembrar que essas organizações eram submetidas aos dispositivos de controle da coroa portuguesa. Na maioria das vezes necessitava de uma série de dispositivos para ter a seu funcionamento autorizado, como o compromisso, que se assemelhava a um regimento interno e documento de fundação, com o nome e a função dos membros e suas obrigações.

Estas entidades fizeram com que os africanos e seus descendentes pudessem se inserir na religiosidade católica trazida do continente europeu pelos colonizadores, por isso, ordens religiosas representaram um papel importante na disseminação das devoções adotadas e transformadas pela população negra. (REGINALDO, 2011, p.134). Na extensão de grande parte do território brasileiro, as irmandades negras se instalaram e desenvolveram diferentes tipos de tradições culturais negras. Historiadores se debruçaram sobre o estudo do desenvolvimento destas irmandades em diversas cidades para assim compreender, como elas influenciaram o desenvolvimento social da região e quais foram suas influências na religiosidade negra. Sendo assim, alguns trabalhos são pontos chave para a compreensão do papel dessas irmandades no Brasil.

Mariza de Carvalho Soares (2000), analisa a região urbana do Rio de Janeiro e afirma que o número de irmandades cresceu muito na segunda metade do século XVIII, com procissões cada vez mais cheias de adeptos. Na sua dinâmica interna, as irmandades cariocas passavam por conflitos que ocorriam com o poder eclesiástico ou originavam-se de disputas internas. $\mathrm{Na}$ organização destas irmandades, a sua origem e a hierarquia a ser respeitada eram dois princípios essenciais, tanto internamente, entre os membros das irmandades, quanto externamente, quando eram comparadas a outras irmandades e com as organizações eclesiásticas.

Em Minas Gerais, Caio Boschi (1986) explica que as irmandades foram um dos fatores responsáveis pela criação de laços sociais ou por manter laços já preexistentes, proporcionando o elo de identidade entre os seus membros, mesmo que estes fossem provenientes de diferentes regiões do continente africano ou nascidos na colônia. Essas confrarias também proporcionaram um processo de construção 
identitária, fazendo perdurar a resistência das tradições africanas e serviram como um espaço de compartilhamento e consolo das experiências vividas pela população cativa. Este representava um dos poucos espaços de sociabilização dos negros ao longo do período colonial.

No contexto baiano, Lucilene Reginaldo (2011), em seu trabalho "O Rosário dos Angolas", explica que haviam irmandades na Bahia com irmãos pretos e pardos, devotos de Nossa Senhora do Rosário, desde o início do século XVII. Em nome desse culto, ergueram-se a capela das Portas do Carmo, juntamente com a Irmandade do Rosário dos Pretos da Freguesia de São Pedro. Posteriormente, outras irmandades foram criadas na Bahia. Com a assimilação dos santos negros, estes assumiram o lugar simbólico de ancestrais poderosos para os africanos e seus descendentes, fenômeno que a autora denominou como "santo parente". Essa apropriação negra dos santos católicos foi essencial para a aceitação e disseminação destas devoções e fé. (REGINALDO, 2011, p.140). Essa apropriação foi extremamente importante tanto para a assimilação das devoções católicas quanto para a associação dos santos católicos aos ancestrais africanos, chamados Orixás pela tradição Iorubá.

A configuração das irmandades negras na Bahia possibilitou uma organização de poder paralela à organização eclesiástica e o surgimento de mecanismos burocráticos informais. Assim, as irmandades proporcionaram a reunião e resistência destas pessoas, o que possibilitou uma série de ações como a articulação de levantes armados e encobrir a fundação de um dos primeiros candomblés da Bahia, assim como fez a Irmandade do Senhor Bom Jesus dos Martírios da Igreja da Barroquinha, (SILVEIRA, 2006, p.150) ou as irmandades de pretos do Rosário, que representavam uma instituição de grande força política e auxílio entre os irmãos, além da função religiosa. (REIS, 1996, p.7)

A participação feminina dentro das irmandades negras foi variável de acordo com o contexto local e com cada organização especificamente, o que torna o caso da Boa Morte muito especial, afinal, a grande maioria das Irmandades erguidas nos séculos XVIII e XIX, a quantidade de mulheres nestas organizações era sempre menor do que a quantidade de homens. (SOUZA, 2007, 41).

Como já citado anteriormente, as irmandades católicas de negros tinham como função, além do culto católico, a manutenção de auxílios financeiros para seus irmãos, a disponibilização de funerais, entre outros tipos de ajuda. (REGINALDO, 2009, p.27). Nesse sentido, é importante destacar a Irmandade da Nossa Senhora da Boa Morte, que 
além destas funções, exerceu e exerce até os dias de hoje um grande papel de símbolo de resistência para o povo negro. Tal atribuição se dá devido ao fato da Irmandade da Boa Morte ter realizado ativamente um papel abolicionista ao longo do século XIX, seja através de compra de alforrias ou de esconderijo para cativos, cumprindo assim o seu importante papel político para a população negra. Paralelamente, a Irmandade também possibilitou a fundação de terreiros de candomblé de diferentes tradições mantendo vivas as tradições africanas amalgamadas pela diáspora.

A Irmandade da Boa Morte é um importante exemplo de preservação de tradições culturais e religiosas, seja desde rituais sagrados de portas fechadas, restrito apenas a integrantes da confraria, até ações cotidianas de exaltação e valorização da cultura afrobrasileira até os dias atuais.

\section{O histórico de cidade de Cachoeira e a Irmandade da Boa Morte}

A história da Irmandade da Nossa Senhora da Boa Morte não pode ser desassociada do crescimento da Vila de Nossa Senhora do Rosário do Porto de Cachoeira, localizada no Recôncavo baiano e elevada à categoria de cidade no ano de 1837 .

Na segunda metade do século XVIII, Cachoeira se encontrava em ascensão comercial devido a produção e exportação de fumo. O rio Paraguaçu, que corta a cidade, fazia ser possível tanto o transporte de mercadorias para a baía de Todos-os-Santos escoando a mercadoria, quanto o caminho inverso com produtos para o sertão baiano. (REGINALDO, 2011, p.67)

Assim como outras cidades de interior localizadas em pontos estratégicos para o escoamento de mercadorias, trocas comerciais, produção fumagueira e cultivo de cana de açúcar durante o período colonial, Cachoeira cresceu bastante em termos populacionais e em meados do século XIX, teve o início de sua decadência comercial.

Do povoado primitivo sobre uma colina, a cidade se expandiu ao longo do Paraguaçu com seus sobrados. Para geri-lá, era preciso organizar sua infraestrutura, com a pavimentação de ruas, construção de chafariz público, pontas e cais. A partir do crescimento da cidade instalada num vale e cercada por morros, foi necessário aterrar parte do rio, na segunda metade do século XIX. No período colonial, era frequente medir a colonização a partir da ocupação territorial e não do crescimento populacional, conforme se expandiam engenhos e igrejas, e com estas irmandades e devoção aos santos, elemento marcante da religiosidade local elaborada entre igrejas e terreiros de candomblés (IPAC, 2011. p. 
26).

Após esse período de ascensão, Cachoeira teve o seu declínio comercial devido à queda da produção econômica, por conta do pouco escoamento da produção de açúcar proveniente da ascensão da produção de açúcar extraído da beterraba no continente europeu e a proibição do tráfico de escravos, culminando na abolição, no final do século XIX.

Cachoeira até os dias de hoje é reconhecida como uma cidade importante tanto pelo seu passado quanto para o que representa nos dias de hoje, sendo atrativa turisticamente pelos seus casarões e seu conjunto arquitetônico, suas festividades, seus candomblés e a grande festa da Nossa Senhora da Boa Morte todos os anos no mês de agosto.

O autor Renato da Silveira (2006) nos explica que a Irmandade da Nossa Senhora da Boa Morte de Cachoeira foi fundada em um momento de grandes mudanças e feitos para as tradições religiosas africanas no Brasil, como a fundação do culto aos eguns da Ilha de Itaparica e a grande reestruturação do Candomblé da Barroquinha. A Irmandade da Boa Morte cumpriu e cumpre até os dias de hoje, uma importante missão para os cultos afro-brasileiros:

\begin{abstract}
Assim como a Irmandade do Senhor Bom Jesus dos Martírios era a fachada legal que abrigava o Candomblé da Barroquinha e a associação política dos nagôs-iorubás, a Devoção da Boa Morte abrigava a Sociedade Geledé, ou pelo menos sua direção era integrada pelas mesmas pessoas. Os dados disponíveis apontam para uma irmandade mais aberta, com a participação de crioulos e malês, enquanto que a devoção parece ter sido mais fechada, exclusiva de mulheres nagôsiorubás, exceção feita às suas descendentes crioulas e eventuais aliadas de outras etnias africanas (SILVEIRA, 2006, p.454).
\end{abstract}

Como explica Renato da Silveira, a Irmandade da Boa Morte realizava ritos mortuários ligados a seus ancestrais africanos relacionados a fertilidade e morte, e possui uma estrutura administrativa bastante rígida em relação as membras associadas e a quem é considerado próximo a Irmandade.

Em sua obra recém lançada "Povoamento e formação social de Cachoeira" o historiador Luiz Cláudio Nascimento traz informações muito importantes para as comunidades de matriz africana a respeito da Irmandade da Boa Morte. Ao contextualizar o surgimento da irmandade, o autor explica que, no início do século XIX, um grupo de mulheres, ligadas a fundação do Ilê Iyá Nassô Oká, um dos primeiros candomblés baianos, se filiaram formalmente a devoção de Nossa Senhora da Boa Morte na 
Barroquinha, onde realizavam o culto africano das deusas-mães iorubanas, a Sociedade Geledé $^{2}$ e também formaram uma junta de alforria para libertar sacerdotisas importantes do cativeiro.

Desde de sua transferência para Cachoeira, a Irmandade mantém sua estrutura social e administrativa diferente das demais irmandades. A Irmandade da Boa Morte nunca teve um compromisso ${ }^{3}$, o que as coloca como devotas de Nossa Senhora da Boa Morte, porém sem estarem legalmente inseridas na estrutura da Igreja Católica, (NASCIMENTO, 2020, p.109) sendo denominadas assim como uma irmandade leiga, status comum entre as Irmandades negras do situadas nos séculos XVIII e XIX. É interessante o fato de que mesmo não estando inserida institucionalmente na igreja, a Boa Morte manteve uma série de normas e preceitos semelhantes a outras organizações, como a festa anual da santa de devoção, a eleição de uma mesa diretora e até mesmo a organização de uma irmandade, porém com o fato de ser constituída estritamente por mulheres negras. De acordo com o Título LX do Livro Constituições Primeiras do Arcebispado da Bahia, as Confrarias que forem erigidas sem a autorização do arcebispado devem ser visitadas por seus oficiais, afim de regularizar sua situação, onde o compromisso deveria ser analisado para que abusos e obrigações fossem corrigidos pelas autoridades em questão. (VIDE, 1853, 336)

Tais características trazem duas reflexões: a de sua fé e devoção em Nossa Senhora e sua adesão a toda a estrutura para o seu culto. Ao mesmo tempo, tal esforço para o cumprimento de todos os preceitos e normas de acordo com as outras irmandades do período, podem ser uma maneira encontrada pelas mulheres da Boa Morte de passarem desapercebidas, e não chamarem a atenção das autoridades para possíveis adequações requeridas.

Podemos assim pensar que originalmente a Boa Morte não era uma irmandade no modelo que concebemos todas as outras que existiram em todo o Brasil, e sim um grupo de mulheres economicamente emancipadas e idosas, que se organizava num grupo feminino de representação de status, que se reunia anualmente para celebrar seus ancestrais, mascarada sob o culto de assunção e morte de Maria. (NASCIMENTO, 1999, p. 109)

\footnotetext{
${ }^{2}$ Corporação político-religiosa feminina, de origem Ketu, que celebrava forças cósmicas e seus poderes, seus cultos tinham ligação com as divindades associadas a fertilidade e a terra.

${ }^{3}$ Compromisso era o documento que regulamentava o funcionamento das Irmandades em todo o território da colônia, perante a Igreja Católica, segundo as "Constituições Primeiras do Arcebispado da Bahia" do ano de 1707. O compromisso funcionava como um regimento da organização, onde era exposto qual a função detalhada de seus irmãos e quais eram suas atividades.
} 
Em outra obra, Nascimento demonstra que a irmandade passou por várias mudanças na sua organização, desde seu período de fundação até 1999, e explica que a Irmandade nunca foi uma instituição pertencente a Igreja, mesmo com sua forte devoção à Nossa senhora.

\begin{abstract}
A importante lição que tiramos desse debate é que ainda estamos longe de entender o papel político que o negro engendrou nas suas estratégias de resistência cultural e de manutenção do ethos africanos no Brasil. Neste sentido, torna-se imprescindível definir o que de fato representaram as irmandades religiosas negras, que tipo de catolicismo praticava na Igreja, o conceito de crença entre os católicos negros, praticantes, ao mesmo tempo, do candomblé (NASCIMENTO, 1999, p.46,47).
\end{abstract}

Além da organização administrativa da irmandade, existe ponto importante e essencial em relação as Irmãs, a maioria delas representam um ponto fora da curva em relação a maioria das experiências de comunidades de africanos escravizados pela diáspora, onde as famílias eram dissolvidas e separadas propositalmente pelos senhores, como uma forma de enfraquecimento dos laços afetivos ${ }^{4}$. Elas insistentemente perpetuaram sua descendência desde sua criação, por volta de 1810 a 1820, ainda na Igreja da Barroquinha em Salvador:

Embora obviamente fossem descendentes de africanas, elas pertenciam a uma linhagem familiar construída na escravidão ou vinda e permanecida na Bahia; esse dado é importante porque houve casos, em Cachoeira e São Félix, em que parte de famílias africanas chegaram juntos em situação de escravização. Ou seja, a Irmandade da Boa Morte é uma corporação religiosa formada por famílias, em que uma filha substitui a mãe, que é substituída pela neta, e assim sucessivamente (NASCIMENTO, 2020, p.129).

A organização interna é bastante rígida hierarquicamente e administrativamente, nesse sentido, os cargos são crescentes. Quando uma irmã é escolhida para ser uma espécie de noviça da irmandade ela exerce uma função específica de Irmã de Bolsa, responsável por recolher doações em dinheiro para que a festa aconteça. Sucessivamente, de acordo com a idade de cada irmã, os cargos vão sendo designados no início do mês de

\footnotetext{
4 As comunidades e organizações negras foram constituídas em meio a desagregação familiar que é resultado do tráfico de escravizados e as dificuldades vividas por essas pessoas. As tentativas de con strução de um vínculo familiar eram frequentemente destruídas por vendas de escravizados, sendo assim, os valores culturais e os laços criados foram fundamentais para a recriação social e cultural afro-brasileira. (ALBUQUERQUE; FRAGA FILHO; 2006)
} 
agosto $^{5}$ antes da festa, para se definir a organização da festa do ano seguinte. Os cargos assim como os das irmandades convencionais são Escrivã, Tesoureira, Procuradora Geral, Provedora e Juíza Perpétua, cargo ocupado pela irmã mais velha da irmandade.

Desta maneira, a Devoção da Boa Morte se mostra uma instituição essencial na construção e permanência de identidades afro-brasileiras nas terras da América, preservando ao longo de sua existência, a memória de mulheres negras do período colonial até os dias de hoje.

O autor Marcos CARVALHO (2006, p.15), que escreveu sobre a trajetória de Gaiaku Luiza, afirma em relação a Boa Morte, que:

Provavelmente no final do século XVIII, várias africanas libertas e endinheiradas, de maioria nagô, originárias do reino de Ketu, no antigo Daomé, passam a assumir este culto, depois transferido para a Igreja da Barroquinha, que pertencia, desde 1764, à Irmandade de Nosso Senhor dos Martírios, formada por negros libertos jejes. Ali, essas negras kétu, "enérgicas e voluntariosas" (verger), se uniram ao ramo feminino da Irmandade dos Martírios, constituindo por africanas jejes, esposas e parentes dos negros jejes formadores dessa Irmandade, localizada no bairro negro da Barroquinha, para cultuarem exclusivamente, Nossa Senhora da Boa Morte. A irmandade não era igual a tantas outras existentes em Salvador. As negras que a formavam, jejes e ketu em sua maioria, camuflavam o culto aos Orisá com o culto católico à morte e assunção de Virgem Maria (CARVALHO, 2006, p.15).

Neste contexto, a Irmandade da Nossa Senhora da Boa Morte de Cachoeira chama atenção devido ao fato de ser uma das mais antigas confrarias e trazer em sua ritualística, tradições culturais católicas e ser comandada por mulheres do Candomblé. A Irmandade é composta apenas por mulheres, que conseguiram fundar a instituição no século XIX, em um contexto totalmente desfavorável e perpetuaram seus cultos e tradições até os dias de hoje. A organização é conhecida mundialmente, principalmente por sua festa anual, que acontece no mês de agosto.

O fato é que durante os três primeiros anos da década de 20, do século XIX, a população baiana se viu fortemente envolvida nos conflitos pela independência, compondo conforme assinala Barcelar apud Falcon (s/d), In: (www.geocities.com/Wellesley/4328/historia.htm) um foco de resistência ao domínio Lusitano. Nesse contexto, boa parte da população, inclusive escravos, se vê engajada nesse movimento que até então consolida uma 'unidade' momentânea de luta pela independência, sendo que esse movimento por ora estendido ao Recôncavo, contribui

\footnotetext{
${ }^{5}$ A festa da Nossa Senhora da Boa Morte acontece dos dias 13 a 17 de agosto, na sede da Irmandade e uma semana antes, as irmãs decidem a comissão da festa do ano seguinte.
} 
de certo modo para os constantes deslocamentos dos negros às cidades do Recôncavo, resultando dessa conjuntura, "inúmeras iniciativas religiosas e civis dos escravos, entre as quais, quem sabe, a própria Irmandade da Boa Morte".

Há ainda outras opiniões acerca da mudança da Irmandade da Boa Morte para a cidade de Cachoeira, opiniões que são partilhadas pelas próprias adeptas dessa ordem religiosa, que na figura de Valmir Pereira dos Santos, secretário da Irmandade da Boa Morte, narra que esta teria sido expulsa da Igreja da Barroquinha. Tal fato teria ocorrido uma vez que o culto singular dessa ordem congrega não somente aspectos de cunho católico, mas também uma forte tendência a rituais profanos característicos do candomblé (CIDREIRA e RIBEIRO, 2008.).

CONCEIÇÃO $(2017$, p.64,65.) define a Irmandade da Boa Morte como:

uma organização formada por mulheres negras, cujos princípios religiosos orientadores são o catolicismo e o candomblé. O objetivo é render homenagem às irmãs falecidas através dos rituais mortuários de matriz africana, que se misturam aos rituais católicos; porém, o estilo que verdadeiramente orienta suas vidas parece ser mais o africano, ainda que os rituais estejam reelaborados e ressignificados. Eles preservam marcas trazidas pelas primeiras mulheres que aqui chegaram forçadamente. Tem-se, assim, a união de duas diferentes formas de conceber a morte e a vida - a ocidental e a africana -, o que aqui chamo de dupla pertença. ${ }^{6}$

Com tais transformações tão marcantes e essenciais para a Irmandade e sua manutenção ao longo de quase dois séculos de existência, supõe-se que as estratégias traçadas pelas irmãs passaram por modificações no fazer político, na relação social entre as irmãs e as outras pessoas externas à organização, na sua festa e principalmente no culto religioso, que coloco como prioridade nas atividades da Irmandade. Tanto o sincretismo interno, quanto o sincretismo estratégico ${ }^{7}$, certamente foram grandes aliados no sentido de perpetuar as tradições da Boa Morte e fazê-las permanecer existindo através do mais diferentes contextos e transformações, além de terem possibilitado o nascimento e a

\footnotetext{
${ }^{6}$ Sobre a dupla pertença religiosa, (SANTOS, 2018, 135) nos explica que a inserção em uma irmandade de culto católico concomitantemente com o fato de ser filha de santo, possibilitou a preservação de tradições e a criação de novos cultos. Permitindo tanto a devoção aos santos católicos quando aos seus orixás de maneira coexistente.

${ }^{7}$ Em seu texto, "Olhares sobre os candomblés na encruzilhada: Sincretismo, pureza e fortalecimento da identidade", (FLOR DO NASCIMENTO, 2017) denomina de sincretismo interno, aquele que se deve a história de nascimento dos cultos que agruparam divindades no Brasil, quando tais divindades eram cultuadas separadamente no continente africano. Tal fenômeno não envolveu elementos religiosos que não fossem provenientes das práticas africanas, elemento essencial para o nascimento dos candomblés. $\mathrm{O}$ sincretismo estratégico se caracteriza por ser uma tática de sobrevivência das crenças africanas, estabelecendo uma ligação com um santo cristão, sem que essa relação afetasse negativamente nos cultos tradicionais.
} 
disseminação do Candomblé. Se faz importante apontar que o sincretismo estratégico amplamente citado e colocado como resultado pacífico da fusão de culturas existentes no Brasil, foi uma narrativa construída sob a diminuição e o desprezo das culturas e espiritualidades africanas, trazendo, na maioria das vezes, exemplos que exaltam a contribuição cristã e diminuem as contribuições de origem africana. (NASCIMENTO, 1978, p.108-111).

A Irmandade da Nossa Senhora da Boa Morte é um símbolo de resistência, de exaltação da cultura e da religiosidade negra, de luta contra o racismo. A importância da Irmandade é reconhecida nacionalmente e internacionalmente pela sua luta antiescravista e pelo trabalho que fazem até os dias de hoje. Sendo assim, se faz necessário compreender como a Boa Morte se organizou e fortaleceu durante o século XIX, para construir as estruturas que as mantem vivas até os dias de hoje. Torna-se importante saber quem foram estas mulheres que se articularam de maneira que permitiram a construção da Irmandade enquanto instituição política com um legado muito importante para a luta antiescravista e viabilizaram o nascimento dos candomblés.

O nascimento ou renascimento da Irmandade da Boa Morte em Cachoeira e sua permanência ao longo destes 200 anos, traz uma lição valiosa a respeito da produção de conhecimento e nos explica muito sobre o que pode ser mais valioso ainda: as estratégias de sobrevivência dos cultos negros no Brasil. A congregação é um patrimônio afrobrasileiro vivo, que deve ser cultivado e exaltado, e deve servir de referência para as experiências afrodiaspóricas no mundo todo.

Mesmo que o campo da História e a produção acadêmica tradicional não volte seu olhar para algumas organizações que se comportam como a Irmandade da Boa Morte e, em alguns momentos e, consequentemente, não as valorize o quanto deveriam, devemos continuar produzindo um conhecimento que consiga representar estas organizações com maior abrangência.

Ainda existem enormes lacunas a respeito da História da Irmandade, porém, sempre respeitando os desejos e preceitos religiosos das próprias irmãs, devemos procurar sempre saber mais a respeito de sua história, porém, também devemos atentar para um ponto crucial para o entendimento da organização: a sua agência e intencionalidade no intuito de não deixar explícito algumas nuances dessa trajetória. 


\section{As detentoras do Awo}

Em uma breve análise, podemos compreender a complexidade dessas nuances históricas: Suas hierarquias, organização financeira, perpetuação da espiritualidade africana, o refinados pré-requisitos e a seleção minuciosa para entrada na irmandade, a sua influência política, o seu capital financeiro do passado, o cuidado e a reverencia as irmãs ancestrais, o senso de comunidade e os costumes alimentares. Com tanta riqueza de detalhes, porque que ainda é “difícil” traçar uma trajetória nítida sobre elas?

Em pesquisas sobre bibliografia, documentação (ou a falta de documentação), e diferentes versões sobre sua data de fundação, pude perceber que essas ditas "contradições" de narrativas foram e são essenciais para que a irmandade resista por tanto tempo e elas não devem ser encaradas como um problema, mas sim aceitas como parte desta trajetória, como ponto essencial na manutenção de suas tradições e necessárias para que se cultivem o awo ${ }^{8}$ e suas tradições, assim como também suas transformações, que desta maneira, são realizadas pelas próprias irmãs, e não por desejos e necessidades externos a congregação.

\section{O "problema" da metodologia}

Já se sabe que a validade ou a confiabilidade dos relatos orais são colocadas em cheque, quando comparadas aos relatos escritos tão amplamente estudados e tidos pela historiografia como "tradicionais". Porém, mesmo em uma situação de desconfiança, tais visões simplistas podem de certa maneira, auxiliar a pesquisa histórica baseada na oralidade, no sentido de que estas constantes críticas fazem com que profissionais que se debruçam em relatos orais estejam sempre atentos ao seu método e seu fazer historiográfico (FERREIRA, 2002, p.327). Assim como explica a professora Marieta de Moraes no trabalho "História, tempo presente e história oral", a história oral como método historiográfico possui tanto rigor científico quanto outro método de análise de maneira que, tal método não representa menos segurança para historiadores que estão preocupados com o os usos da oralidade para servir a interesses políticos e ideológicos. (FERREIRA, 2002, p.329).

Seja por ingenuidade ou por qualquer outro motivo, é de conhecimento de todos

\footnotetext{
${ }^{8}$ Awo em Iorubá, significa ‘segredo' elemento essencial presente nas religiões de matriz africana.
} 
que se dedicam ao estudo da História, que não existem trabalhos de pesquisa que não possuam suas escolhas políticas. Por consequência, é sabido o porquê de temas que envolvem candomblés, macumbas, calundus, batuques e outros cultos e tradições de pretas e pretos, assim como este aqui trabalhado, não são abordados por alguns cientistas e quando são, trazem uma visão completamente estereotipada e distorcida das realidades vivenciadas, a serviço de reforço de estereótipos racistas e imaginários.

O relato oral sobre as memórias individuais diz muito, não apenas sobre o que está sendo contado, diz também bastante sobre quem está contando tal relato e quais são suas concepções e visões, devido ao fato de que estas memórias são construídas através do que foi representativo sobre o passado para quem está trazendo um depoimento. Além disso, é importante salientar que existem conexões entre as memórias pessoais e as memórias coletivas, enquanto que, relatos pessoais, quando colocados em conjunto, apontam para relatos construídos por uma memória coletiva, agregando valor a estes sinais que não variam. (POLLAK, 1992).

Nas comunidades provenientes da diáspora africana, a memória é preservada e transmitida através da oralidade, diferentemente da tradição eurocêntrica, que prioriza a escrita em favor da palavra falada. Segundo HAMPATÉ BÂ (1982, p.180), as tradições africanas prezam pela oralidade como canal de transmissão de conhecimento, poder e representam sabedoria e autoridade. O autor explica que a importância dada a cada uma das maneiras de transmissão de conhecimento, se dá de acordo com o valor que a própria sociedade em questão atribui a tal forma de transmissão:

... não é esta a maneira correta de se colocar o problema. O testemunho, seja escrito ou oral, no fim não é mais que testemunho humano, e vale o que vale o homem. [...] [...] Nada prova a priori que a escrita resulta em um relato da realidade mais fidedigno do que o testemunho oral transmitido de geração a geração (HAMPATÉ BÂ, 1982, p.181,182).

A tradição oral é importante para as comunidades africanas e não pode ser colocada em patamares abaixo da tradição escrita, assim como foi realizado por costume no mundo ocidental, afinal de contas um documento escrito pode servir a interesses específicos, escondendo ou desvelando detalhes, tanto quanto um relato falado. Neste sentido, um testemunho se torna bastante importante ao se tratar do passado pois além de elucidar sobre fatos acontecidos, também traz a importância e o sentido que aquele fato possui na perspectiva de quem o está narrando. Nas sociedades que prezam o conhecimento oral, a palavra tem um valor maior do que nas sociedades em que se 
apegaram a escrita e uma grande valorização das representações criadas pela memória. (HAMPATÉ BÂ, 1982, p.180)

No contexto das Irmandades Negras, a oralidade se faz essencial para compreensão de vivências dos indivíduos ou de entidades inteiras, no sentido que trazem à tona dimensões acerca do passar do tempo e revelam diferentes percepções tanto com o que é falado, quanto o que não é falado, trazendo novas possibilidades para o estudo da organização. (SANTANA, 2013, p. 38-40)

Além do validade e importância da palavra dita e do cuidado com a transmissão do conhecimento através da fala trazido como herança da travessia de África, existe o fato de que o sistema escravagista dificultou bastaste as possibilidades de letramento de escravizados, especialmente após 1835, quando foi proibido que escravizados frequentassem escolas (PERES, 2020, p.162), tornando assim, a oralidade como meio de comunicação mais eficaz e de maior entendimento para a população preta.

Assim como a Boa Morte, outras organizações também não possuem acervo documental escrito que possam servir como fontes comprobatórias escritas de sua fundação, funcionamento, porém isso não pode ser um impeditivo para seu estudo e para seu devido reconhecimento.

A aclamada autora Nigeriana, Chimamanda Ngozi Adichie, em seu discurso, posteriormente publicado como o livro: "O perigo da História Única" fala de maneira simples e certeira sobre o ponto:

As histórias importam. Muitas histórias importam. As histórias foram usadas para espoliar e caluniar, mas também podem ser usadas para empoderar e humanizar. Elas podem despedaçar a dignidade de um povo, mas também podem reparar essa dignidade despedaçada; [...]Eu gostaria de terminar com esta ideia: quando rejeitamos a história única, quando percebemos que nunca existe uma história única sobre lugar nenhum, reavemos uma espécie de paraíso (Adichie, C. N. (2009).

A importância das diferentes narrativas é essencial para trazer uma história representativa a respeito de fatos e trajetórias. Assim sendo, se faz essencial, ao se tratar de populações pretas, escutá-las, através de diferentes meios, e não apenas com livros e documentos escritos, possibilitando assim, decifrar explicações para questões travadas por tradições impostas à população diaspórica preta, trazendo à tona suas agências, estratégias e protagonismo. 


\section{Conclusão}

É essencial, como já dito aqui anteriormente, a importância e o legado construído pela Irmandade da Nossa Senhora da Boa Morte e igualmente essencial, a conscientização a respeito dessa organização e do que ela representa enquanto instituição de mulheres negras anciãs, detentoras de conhecimento, dos segredos e espelho para tantas outras mulheres negras. Sua história, quando colocada em um olhar mais atento, traz uma série de pontos chaves primordiais para se compreender a nossa construção cultural e social.

Ainda há muito o que ser reverenciado, estudado e reconhecido, como o nascimento do samba, que é um dos símbolos importantes de identidade nacional, ou a possibilidade de organização dos candomblés da Bahia. Estes e outros assuntos não citados e explorados nesse trabalho possuem uma forte ligação completamente entrelaçada com a Irmandade da Boa Morte. Deve-se muito a estas mulheres e também temos muito o que aprender com elas.

Em tempos tão inseguros e inconstantes em relação a retirada progressiva de direitos da população preta, devemos olhar para trás e aprender com essas mulheres, para que no futuro possamos também dizer que também conseguimos e que existimos. Se ao longo da História do Brasil, a tentativa de destruição através de um projeto de apagamento da população preta foi constante e dura, tenhamos a certeza que existem projetos de existência e perpetuação muito maiores e bem sucedidos, vencedores... Sim, vencedores, porque (re)existências pretas existem e continuarão existindo. 200 anos não são 200 dias. Viva a Irmandade da Boa Morte! Viva Nossa Senhora da Glória! Axé!

\section{Bibliografia}

Adichie, C. N. (2009). O perigo da história única. Disponível em http://www.ted.com/talks/lang/pt/chimamanda adichie the danger_of a single_story.h tml Acesso em 25 Abril 2018

ALBUQUERQUE, Wlamyra Ribeiro de; FRAGA FILHO, Walter. Uma história do negro no Brasil. Salvador, Centro de Estudos Afro-Orientais; Brasília, DF: Fundação Cultural Palmares, 2006.

Bahia. Governo do Estado. Secretaria de Cultura. IPAC. Festa da Boa Morte. Salvador: Fundação Pedro Calmon / IPAC, 2011

BOSCHI, Caio. Os Leigos e o Poder (Irmandades Leigas e Politica Colonizadora em Minas Gerais). Editora Ática, 1986 
CARVALHO, Marcos. Gaiaku Luiza e a trajetória Jeje-Mahi na Bahia. Rio de Janeiro: Pallas, 2006.

CIDREIRA. Renata Pitombo; RIBEIRO, Vanhise da Silva; SILVA, Aline Pires. "Irmandade da Boa Morte: Simbologia dos Trajes e Reforço à Identidade Sincrética." p. 2. In: Intercom - Sociedade Brasileira de Estudos Interdisciplinares da Comunicação. $X$ Congresso de Ciências da Comunicação na Região Nordeste - São Luis, MA - 12 a 14 de junho de 2008.2 Disponível em: http://www.intercom.org.br/papers/regionais/nordeste2008/resumos/R12-0417-1.pdf

CONCEIÇÃO, Joanice. Irmandade da Boa Morte e Culto de Babá Egum: Masculinidades, Feminilidades e Performances Negras. Jundiaí: Paço Editorial, 2017.

DO NASCIMENTO, W. F. Olhares sobre os Candomblés na encruzilhada: Sincretismo, pureza e fortalecimento da identidade. Revista Calundu, v. 1, n. 1, 5 jul. 2017.

FERREIRA, Marieta de Moraes. História, tempo presente e história oral. Topoi (Rio J.), Rio de Janeiro, v.3, n.5, p.314-332, Dec.2002 . In: https://www.scielo.br/pdf/topoi/v3n5/2237-101X-topoi-3-05-00314.pdf Acesso em: 25 set 2020 .

HALL. Stuart. Da Diáspora. Identidades e Mediações Culturais. Belo Horizonte: EdUFMG/Humanitas, 2003.

HAMPATÉ BÂ. A. “A tradição viva.” In: KIZERBO, J. História Geral da África Metodologia e pré-história. São Paulo: Ática, Paris: UNESCO, 1982.

IBGE - Instituto Brasileiro de Geografia e Estatística. A população negra no Brasil. In: https://brasil500anos.ibge.gov.br/en/territorio-brasileiro-e-povoamento/negros/populacao-negrano-brasil Acesso em 22/11/2019.

NASCIMENTO, Abdias Do. O genocídio do negro brasileiro: processo de um racismo mascarado. São Paulo: Editora Perspectiva, 2016.

NASCIMENTO, Luiz Claudio, "Mulheres (Des)ordeiras: culto ancestrais na Irmandade da Boa Morte, 1999, texto inédito.

NASCIMENTO, Luiz Cláudio do. Povoamento e Formação Social de Cachoeira. 2020.

PERES, Eliane. A aprendizagem da leitura e da escrita entre negras e negros escravizados no Brasil: as várias histórias dos "sem arquivos". Cadernos de História da Educação, v.19, p 149-166, Jan-Abr, 2020.

POLLAK, Michel. Memória e Identidade Social. Estudos Históricos. Rio de Janeiro, Vol. 5, n. 10, 1992

REGINALDO, Lucilene. Irmandades e devoções de africanos e crioulos na Bahia setecentista: histórias e experiências atlânticas. In: Stockholm review of Latin American studies. Disponível em: http://www.lai.su.se/publications/stockholm-review-of-latinamerican-studies/list-of-issues/issue-no-4-march-2009-1.135159 Acesso em 15/10/2017. 
REGINALDO, Lucilene. Os Rosários dos Angolas: Irmandades de Africanos e Crioulos na Bahia Setecentista. São Paulo: Alameda, 2011.

REGIS, Mariana Fernandes Rodrigues Barreto. "Dizem os Irmãos": Propostas metodológicas de análise de um compromisso de Irmandade no período colonial. Dissertação (Mestrado) - Universidade de Brasília, Brasília, 2016.

REIS, João José. Identidade e Diversidade Étnicas nas Irmandades Negras no Tempo da Escravidão. Tempo, Rio de Janeiro, vo.2, n³, 1996.

SANTANA. Analia. A participação política das mulheres na Irmandade de Nossa Senhora do Rosário dos Homens Pretos do Pelourinho (1969 - 2001). Dissertação (Mestrado) - Universidade do Estado da Bahia, Salvador, 2013.

SANTOS, Mariana de Mesquita. PELAS CONTAS DO ROSÁRIO: Cidadania na Irmandade de Nossa Senhora do Rosário dos Homens Pretos do Pelourinho no PósAbolição (Salvador, 1888-1930). Dissertação (Mestrado) - Universidade de Brasília, Brasília, 2018.

SILVEIRA. Renato da. O Candomblé da Barroquinha: processo de constituição do primeiro terreiro baiano de Ketu. Salvador: Edições Maianga, 2006.

SOARES, Mariza de Carvalho. Devotos da Cor. Rio de Janeiro: Civilização Brasileira, 2000.

SOUZA, Wiltércia Silva de. O sequestro das santas: A Irmandade da Boa Morte e a Igreja Católica em Cachoeira, Bahia - 1989. Dissertação (Mestrado) - Universidade do Estado da Bahia, Santo Antônio de Jesus, Bahia, 2007.

THORNTON, John Kelly. A África e os Africanos na formação do mundo atlântico, 1400-1800. Rio de Janeiro: Elsevier, 2004.

TVE BAHIA, Irmandade da Boa Morte | TVE Bahia. Youtube, 02 dez 2019. Disponível em: https://www.youtube.com/watch?v=zkV5EWEm_iQ Acesso em: 20 set 2020.

Vide, Sebastião Monteiro da. (1853). Constituições primeiras do Arcebispado da Bahia feitas, e ordenadas pelo Illustrissimo, e Reverendissimo Senhor D. Sebastião Monteiro da Vide : propostas, e aceitas em o Synodo Diocesano, que o dito Senhor celebrou em 12 de junho do anno de 1707. Acesso em: https://www2.senado.leg.br/bdsf/handle/id/222291 Consultado em 20 de 10 de outubro de 2020.

Recebido em: 04/10/2020

Aceito em: 07/10/2020 